YIRA LAZALA ${ }^{1}$

\title{
Spatiality, Temporality and Ontology: Constraints for the Restitution of Indigenous Peoples' Territorial Rights in Colombia
}

\section{Introduction}

In this article, three limitations to how ethnic land restitution has been carried out in Colombia to date are discussed. The specific restrictions that I mention are related to 1) temporality, 2) spatiality, and 3) to the ontology of the idea of reparations concerning indigenous peoples' territorial rights ${ }^{3}$. These findings result from fieldwork conducted in 2017 and 2018 in the Aponte indigenous reserve of the Inga people.

The first section of the article briefly describes the history and functioning of Act 1448 of 2011, known in Colombia as the Law on Victims and Land Restitution. In

1 YIRA LAZALA is a Ph.D. candidate in anthropology and sociology of development at the Graduate Institute of International and Development Studies in Geneva (Switzerland). E-mail: yira.lazala@graduateinstitute.ch. Many thanks to Zahira Araguete Toribio and Aarin Shapiro for meticulously proofreading this article.

${ }^{2}$ This article was originally published in http://www.alternautas.net/blog/2020/4/29/spatialitytemporality-and-ontology-constraints-for-the-restitution-of-indigenous-peoples-territorialrights-in-colombia

3 Territorial rights mean to rule over a territory, including the subsoil, water, and other resources. Territorial rights are inherently collective, and they imply the autonomy to decide how to use the lands and other resources that are contained within a frontier. Indigenous peoples' territorial rights include the right to self-determination, self-government and indigenous justice. Enforced displacement, confinement and forced activities that are not consented by an indigenous people, are violations of territorial rights (Presidencia de la República de Colombia 2011a). 
the second section, I describe the case of the Inga people in Aponte, located in the department of Nariño, in southern Colombia. In the third section, I discuss the three limitations mentioned above regarding the land restitution process, followed by a conclusion.

\section{Armed conflict and land restitution for indigenous peoples}

Since the 1960s, Colombia has lived an armed conflict between left-wing guerrillas, right-wing paramilitary groups, and state forces. Indigenous peoples have been particularly affected by it. According to the last available official figures, 344.947 indigenous people have been displaced during this time frame (UARIV 2019). In 2018, a report by the National Indigenous Organization of Colombia (Organización Nacional Indígena de Colombia - ONIC) signaled that 2,954 indigenous people have been murdered in the conflict, and 1,884 armed confrontations have violated indigenous peoples' territorial rights. In addition, 2,015 cases of threats to indigenous people have occurred, and 123 incidents of killings with multiple victims have taken place in indigenous reserves (ONIC 2018).

The Colombian state has adopted a series of scattered laws and public policies for providing reparations to victims, intending to promote a political solution to the internal armed conflict. These mechanisms intend to consolidate peace and democracy. Nevertheless, they have not represented a unified strategy (Justicia Transitional n.d). The most relevant legal tool for the victims of armed conflict that appeared before the Peace Agreements signed with the FARC in 2016, is Act 1448 of 2011 on Victims and Land Restitution. Through this Act, the government of former president Juan Manuel Santos recognized the existence of the internal armed conflict. This recognition was a radical shift in comparison with the denialist perspective held by the previous president, Álvaro Uribe. Uribe considered guerrilla groups to be narcotraffickers and terrorists, not political actors.

Act 1448 includes a series of ambitious measures to assist and provide reparations for individuals and collectives that have been affected by any of the actors of the 
conflict, comprising the state forces. To do so, it created two specialized public institutions: The Unity for Victims, and the Unity of Land Restitution (from now on URT) (Ministerio de Justicia n.d). Act 1448 of 2011 incorporates a transformative approach. It means that reparations are supposed to transform the social circumstances that produced the damages, not only to re-establish the conditions that existed before them. This perspective is necessary to fulfill a fundamental principle of this Act, which guarantees non-recurrence. To re-establish the situation exactly as it was before extreme acts of violence, characterized by discrimination and vulnerability, would not be enough to build long-lasting peace, justice and a broader democracy (Blanco et al 2017).

Given the high rates of internal enforced displacement in Colombia, one of the most relevant measures of transformative reparation that this act includes is the restitution of abandoned and stripped lands. The process of land restitution has two stages: the administrative and the judicial. URT leads the former. The URT documents the cases, and it includes them in the National Register of Abandoned and Usurped Lands. Then, the URT submits a demand for land restitution to specialized tribunals, where judges or magistrates are responsible for making final decisions. Because of the transformative perspective of Act 1448, the judges in charge have a fundamental role that goes beyond the usual scope of civil law. They have to mobilize constitutional law to make decisions with the capacity of transforming structural inequalities and discrimination that put some social groups in situations of particular vulnerability vis-à-vis armed conflict (Blanco et al. 2017).

Act 1448 puts a time limit for considering cases. Victims can request reparations for the damages that have occurred since 1985. Nevertheless, the restitution of lands can only be demanded for events that occurred after January 1, 1991, coinciding with the year of the adoption of the latest Colombian Constitution. The Act is also limited in terms of its time validity. It was initially established for ten years (20112021). In 2019 it was extended for ten additional years, meaning that it will be in force until 2031(Redacción Judicial 2019).

After the adoption of Act 1448, indigenous and afro-Colombian organizations participated, separately, in the creation of two decrees that incorporate an ethnic differential approach in the provisions created by it (Ruiz 2017). As a consequence, 
Decree-Law 4633 on territorial rights restitution for indigenous communities, and Decree-Law 4635 for Afro-descendant communities were adopted (Presidencia de la República de Colombia 2011a, 2011b). As Ruiz signals, thanks to the engagement of national indigenous peoples' platforms, Decree-Law 4633 incorporated the notion of territory as a victim of internal armed conflict. This idea highlights the vital and spiritual links that indigenous communities establish with the lands that they inhabit. Decree-Law 4633 does not define ancestral territories only as collective property, but also as an indispensable part of indigenous peoples' spiritually and kindship networks (Ruiz 2017).

The concept territory as a victim implies to transform an individualistic and liberal conception of reparations for victims of armed conflict. It highlights the collective dimension of the damages produced by armed conflict. It suggests that the violent rupture of the relationship established by indigenous communities with their surroundings is one of the most destructive effects of armed conflict (Ruiz 2017; Presidencia de la República de Colombia 2011a). Despite the vast normative innovations achieved through the advocacy of indigenous peoples' organizations, in practice, the conception of indigeneity enacted by the Colombian state, impedes the effective implementation of these provisions.

\section{The case of the Inga people from Aponte}

The relevance of a wide conceptualization of the right to territory, as proposed by indigenous organizations in Colombia, is illustrated by the case of the Inga people from Aponte, located in Nariño, in southern Colombia. During my fieldwork in this community in 2017 and 2018, professionals from the URT came to collect information to develop a demand for the restitution of territorial rights, in the frame of Decree-Law 4633. The lawsuit of the Inga from Aponte was sent to the Land Restitution Court in the city of Pasto (capital of Nariño) in late 2018. At the 
moment of writing, the request has still not received a final decision ${ }^{4}$.

The Inga are a community of Quechua origin that inhabits several departments of southern Colombia. They began settling in the area where the Aponte reserve is located today in the XVI century, when some Inga families arrived from the department of Putumayo (Cabildo Mayor del Pueblo Inga de Aponte 2009). In the late 1980s and early 1990s, settlers from all around the country came to this reserve, attracted by the area's flourishing business of illegal poppy crops and heroin production. This activity emerged as a lucrative alternative to widespread poverty and state neglect experienced by the local population. Heroin trafficking became a significant source of funding for several armed groups in the region, as multinationals of illicit drugs were expanding (UNDP 2019).

Armed groups started to dispute the control over the territory and trafficking networks in Aponte. At the end of the 1990s, paramilitary attacks began, based on the accusation that local residents were 'abettors of the insurgency.' As a response to the expansion of illicit crops, the Colombian government launched a campaign of large-scale aerial crop spraying with glyphosate. Glyphosate fumigations caused profoundly negative environmental and social impacts, adding to the numerous human rights violations suffered by the Inga people and peasant settlers in Aponte (UNDP 2019).

Inga people have lived in this region of Nariño since the XVI century. However, only in 2003, they obtained the legal recognition of their territory as a contemporary indigenous reserve. From that moment onward, they began a process of institutional reform that allowed them to eradicate illicit crops from their entire territory, with the support of a government-funded program for voluntary manual eradication. The elimination of poppy crops prompted the departure of armed groups. As part of their process of institutional strengthening after this withdrawal, community leaders approached the URT in 2015 to request the restitution of their

\footnotetext{
${ }^{4}$ As of September 30, 2019, only 14 sentences of ethnic territorial rights restitution have been emitted, in almost ten years of operation of Act 1448. Furthermore, the implementation of the measures of integral reparation included in the issued sentences is deficient (AURIV 2019).
} 
territorial rights. This process constitutes an example of the ways in which indigenous peoples contest the limited vision of indigeneity that the Colombian state enacts.

\section{Space, indigeneity and the restitution of territorial rights}

As Radcliffe (2017) signals, indigeneity is a relational position that aims at producing difference in a particular way, which "is always embedded in power differentials at multiple scales" (p. 221). Indigeneity is deeply related to historical and institutional expressions of power regimes. Dynamics of social reproduction, legal titling of lands and construction of conceptions of indigeneity, produce concrete configurations of society and space (p. 226).

The struggle for territorial rights under the figure of the reserve is one of the main priorities of indigenous social movements in Colombia. The spatial limits of the indigenous reserve are also the boundaries of the space upon which the fundamental rights to self-determination and prior consultation contained in Colombia's legal framework can be exerted. Nevertheless, the reserve is not an ancestral form of territoriality ${ }^{5}$.

The current defense by all the ethnic minorities in Colombia of territorial rights in the form of indigenous reserves, it taking place because it serves as a way of

\footnotetext{
5 The indigenous reserves (in Colombia resguardos indígenas) were adopted in 1592 and afterward derogated during the second half of the XVIII century. They were initially constituted to control the indigenous populations by the colonizers, to group them and facilitate the exploitation of their work. In the XX century, the indigenous reserves started to be considered a form of protection against the process of ethnic and cultural amalgamation that Colombia was going through. Finally, with the expedition of Law 135 of 1961 on Agrarian Reform, the titling of lands to indigenous peoples was reactivated (Garzón 2017). In 1991, the new Colombian Constitution recognized indigenous peoples' right to self-determination, to autonomous government, and the right to customary justice systems. That same year, Law 21 of 1991 ratified International ILO Convention 169 on Indigenous and Tribal Peoples. With this, indigenous peoples achieved the recognition of the right to prior consultation regarding any kind of project to be held in the areas recognized as indigenous territory (Pineda 1997).
} 
countering the commodification of land and subsequent cultural assimilation and ethnic disappearance. But many Inga leaders highlight the fact that the indigenous reserve does not match with their ancestral forms of territoriality. Inga people do not consider that their territory is limited to the hectares of land that the state officially recognized as such in 2003, when former Colombian Institute of Rural Reform created the reserve through Resolution 013 (INCORA 2003).

The Inga people, of Quechua origin, came to Nariño from Peru. They continuously circulate around the the Andean mountains, and they consider the entire region to be indigenous territory. Moreover, the indigenous reserve of the Inga of Aponte, originally constituted during colonial rule around 1700, was larger than the area included in the official resolution of adjudication of the collective territory. An Inga elder expressed to me his thoughts in this regard:

The Colombian state wants to lock us up in a cage. We, as a territory, have been locked at this point. But spiritually, we are the owners of this mountain range, of the Doña Juana mountains and all those limits. They are allocating us this point of Aponte, but we are all united. From Caquetá, Putumayo and Cauca. So, we, all the reserves, belong together. We may not come from the same indigenous ethnicity, but since we are grouped within a territorial reserve, we are all stuck together, the whole mountain range [cordillera]. So, they shouldn't look only at the reserve of Aponte; we are the owners of all of this ... the Central Mountain Range until arriving in Peru, all of these are indigenous territories (Inga elder 2018, my translation).

The indigenous reserve results from the strategy of the state to confine difference to better administer it, creating limited and legalized geographical boundaries within which ethnicity can be enacted, differentiated from the dominant mestizo space. Despite attempts by indigenous communities to introduce the concept of territory as a victim into legal land restitution mechanisms, the state's failure to incorporate a wider definition of indigenous territoriality has reinforced the legalized link between indigeneity and an enclosed space (Bocarejo 2014).

Radcliffe states that the definition of indigeneity enacted by modernity's geographical imagination naturalizes its association with "an (almost magnetic) attachment to locale, a once pristine place" (2017, p. 223). This link has significant consequences in the possibilities that indigenous peoples have for undertaking 
certain spatial practices and enacting certain kinds of mobility (Radcliffe 2017, p.223). The Inga leaders expected to obtain more land through the process of territorial rights restitution. According to them, this was the only way of being substantially compensated by the state. One elder explained to me his perspective on the reparations scheme:

If the state wanted to compensate us, the officials should tell us - we have a certain amount of money for you to buy land, not in the reserve, but outside. That would be the only real reparation for us. Families have grown, what has not grown are our lands. We have been victims since colonization... we allocate $50 \%$ or $60 \%$ of our territory to the conservation of forests because this is our priority, so the area that we have for agriculture is not big enough... (Inga elder 2018, my translation)

However, the URT refused to include such a request in the list of pretentions to be sent to the Land Restitution Court. According to them, this was not feasible. As Radcliffe signals, indigenous peoples are subject to forced displacement, promoted in many ways by the same actors who have defined indigeneity as an identity that must be confined within a limited space. She points out that this "highlights how authenticity and 'prior presence' are less relevant than the forms of power and economy that produce indigeneity continuously in relation to the non-Indigenous subjects, sovereignty, environment, the academy, and policy" (2017, p.226).

\section{Land dispossession and the politics of temporality}

Shifting temporalities of justice and indigeneity are at stake in the struggle of the Inga people of Aponte to keep their territorial rights. A central question for the political processes in this community has been whether social justice is found by looking back or ahead. The response from the leaders of the community is that social justice regarding territorial rights is found in the ancestral past, rather than in a future construction.

There is a fundamental contradiction between the temporality of reparations, the temporality of land dispossession, and the temporality under which the members of the indigenous government of Aponte understand the idea of compensation for 
their territorial rights. All these rights claims entangle a conflicting and unsettled notion of the relationships between territory, temporality, law, and politics. The Inga authorities translate the state's legal concept of reparations into the idea of harmonization of the territory. A woman leader of the community explained this concept to me in the following way:

For us, social justice means harmony and spiritual and social balance, which is achieved through respect of oneself, and of nature. Harmony is maintained through our own processes. But not according to what is now, to the current realities that we are living, but rather, according to what should be (lo que debería ser). And of course, to re-establish the order of things as it should be, we don't have to go back in time ten years, but many, many years further back [...] Otherwise, we are condemned to stay in the same situation that we have now (Inga leader 2018, my translation).

For the Inga, the violence exerted against them did not start 60, 50, or 30 years ago. It has been an ongoing process since colonization. To achieve the harmonization of the territory, that according to the leader mentioned above, means 'spiritual and social balance,' it would be necessary to return to the farthest past, exploring the remnants of ancestral memory that are only accessible by spiritual means.

In contrast, dispossession is a reiterative and persistent phenomenon, constitutive of state formation in Colombia. However, current legal definitions of land dispossession indicate that the restitution process is viewed as a direct consequence of the last phase of the internal war in Colombia, and that land restitution can only be requested for cases that occurred since 1991. From this perspective, land dispossession is understood as an exceptional phenomenon, and as a collateral effect of the armed conflict (Raiz-al 2015).

As a consequence, indigenous peoples' victimization is framed as something exceptional, rather than as part of a much longer and broader historical process. Such a frame is embedded in the aspiration to rectify indigenous peoples' continuous collective dispossession through circumscribed legal remedies (Raiz-al 2015). As Meertens (2016) has pointed out, the transformative potential of Act 1448 is related to the exceptionality and temporality of its measures. Nevertheless, 
this is also one of its fundamental limitations regarding the long-lasting, structural land dispossession that indigenous peoples face in Colombia.

Indigenous peoples' vulnerability to human rights violations is related to the ongoing effects of colonial history and its legacies, and not only with the 'exceptional condition of civil war' (Raiz-al 2015). Because of this, the logic of exceptionality of transitional justice, and the logic of repeated dispossession in the history of state formation in Colombia is a contradiction that profoundly affects indigenous peoples. Such opposition prevents a substantial exercise of their recognized fundamental rights. Additionally, the logic of legal remedies as a futureoriented project enters in a strange relationship with the concept of reparation as harmonization of the indigenous territory.

The fact that the state intends to compensate the community only for the processes of land dispossession that took place from 1991 to 2018, in the frame of what it officially recognizes as the internal armed conflict, does not allow the Inga community to obtain meaningful harmonization of their territory. To the indigenous leaders, this would require spiritual healing of the relationship between communities and their territories, guaranteeing durable collective wellbeing and survival over time. The state does not provide sufficient means to reach enduring harmonization. For this reason, it is not possible to guarantee that dispossession will not happen again. Structural conditions of discrimination against indigenous peoples, linked with long-standing historical processes, must be transformed in order to do so.

Despite the recognition of territory as victim in Decree-Law 4633, the way in which this Decree has been applied so far, reinforces a vision of indigeneity that reproduces unequal and fragmented categories of access to citizenship. Paradoxically, this process occurs through the reinforcement of an imperative of ethnic diversity to impoverished rural communities. Ethnic diversity and victimization become the main categories of visibility under which the state perceives them, and through which it appears possible to establish a dialogue about responsibilities to guarantee collective fundamental rights (Ruiz 2017; Bocarejo 2014). 


\section{Ontology of the damages, ontology of the reparations}

One day, during my fieldwork in the Inga reserve, I visited the coffee farm of an older woman to help her harvest the mature red beans. While we worked, she told me about a vision that she had during an ambiwaska ceremony. During her vision, she saw her ancestor, Taita Carlos, crying tears of blood for the destruction of the territory. He felt so sad because his people had allowed illicit crops to be introduced into the territory, because they had permitted deforestation, and many more types of degradation. For her, this vision meant that the territory has not yet regained harmony.

In 2013, nine years after the departure of armed actors from the Inga territory, a massive landslide destroyed the urban center of the indigenous reserve of Aponte. The public school, the church, the building of the indigenous government and almost all of the houses were lost. As a consequence, the Inga members affected by the catastrophe have lived in provisional shelters for the past six years. The authorities of Aponte consider that the 2013 landslide is a consequence of the disharmony between nature, spiritual beings and the community that has existed in their territory since the expansion of heroin production and armed conflict. However, the URT refused to include the landslide and destruction of the urban center of the reserve in the list of damages to be sent to the Land Restitution Court, as part of the demand for restitution of territorial rights. The institution argued that it was not possible to demonstrate a causal relationship between armed conflict and the landslide.

As scholars such as Ruiz (2017) and Jaramillo (2014) have signaled, until now, reparations of victims' rights with a focus on ethnicity in Colombia tend to mobilize preestablished formulas and limited options of possible claims prescribed by the state. In this way, as indicated by Ruiz, through these policies, the distinction between 'knowledge' and 'belief, continues to be reinforced, reducing the possibilities for understanding the harms of armed conflict and its possible remedies (Ruiz 2017).

The decrees of ethnic territorial rights restitution include relevant formal innovations. Nevertheless, how these decrees have been implemented until now by 
the Colombian state, reinforces a definition of indigeneity that reproduces unequal categories of access to citizenship, and to the full enjoyment of individual and collective human rights. This outcome is due in part to the temporality, spatiality and ontology of the idea of reparations that the state enacts. Despite these limitations, indigenous peoples keep contesting and expanding such notions. In this manner, they enlarge the possibilities for expressing their territorialities, temporalities and ontologies.

\section{References}

Blanco, Daniel José, Diana Isabel Güiza, and Camila Andrea Santamaría. 2017. Corregir o Distribuir Para Transformar? Una Concepción de Justicia Para La Política Pública de Restitución de Tierras En Colombia. Bogotá: Universidad Nacional de Colombia.

Bocarejo, Diana. 2014. "Legal Typologies and Topologies: The Construction of Indigenous Alterity and Its Spatialization Within the Colombian Constitutional Court.” Law \& Social Inquiry 39 (2): 334-60. https://doi.org/10.1111/1si.12044.

Cabildo Mayor del Pueblo Inga de Aponte. 2009. Mandato Integral de Vida Para La Pervivencia Del Pueblo Inga En Aponte. Pasto: USAID.

Congreso de la República de Colombia. 2011. "Ley 1448 de 2011. Por La Cual Se Dictan Medidas de Atención, Asistencia y Reparación Integral a Las Víctimas Del Conflicto Armado Interno y Se Dictan Otras Disposiciones." https://www.unidadvictimas.gov.co/sites/default/files/documentosbiblioteca/ley1448-de-2011.pdf.

García, Camilo. 2008. Conflicto, Sociedad y Estado Colonial En El Resguardo de Chiquiza, 1756-1801. Bogotá: Universidad de los Andes, Colombia. 
Garzón, Óscar. 2017. "Constitución y Ampliación de Resguardos Indígenas En Colombia. Una Mirada al Avance Histórico y Perspectivas de Cumplimiento.” Campos En Ciencias Sociales 5 (1 and 2): 73-113 https://ojs.usantotomas.edu.co/index.php/campos/article/view/3804.

Jaramillo, Pablo. 2014. Etnicidad y Victimización. Genealogías de La Violencia y La Indigeneidad En El Norte de Colombia. Bogotá: Universidad de los Andes, Colombia. https://www.jstor.org/stable/10.7440/j.ctt18gzd93.

Junta Liquidadore del Instituco Colombiano de la reforma agraria INCORA. 2003. "Resolución Número 013 de 2003. Por La Cual Se Constituye Como Resguardo, En Favor de La Comunidad Indígena Inga de Aponte, Un Globo de Terreno Baldío, Localizado En Jurisdicción Del Municipio de Tablón de Gómez, Departamneto de Nariño.”

http://siatac.co/c/document_library/get_file?uuid=394991e5-220c-4ec1-b06c6744235e2e86\&groupId=762.

Meertens, Donny. 2016. "Justicia de Género y Tierras En Colombia: Desafíos Para La Era Del 'Pos-Acuerdo.”' European Review of Latin American and Caribbean Studies / Revista Europea de Estudios Latinoamericanos y Del Caribe, no. 102 (October): 89-100.

Ministerio de Justicia. n.d. "Justicia Transicional En Colombia." Accessed January 16, 2020. http://www.justiciatransicional.gov.co/Justicia-Transicional/Justiciatransicional-en-Colombia.

ONIC. 2018. "Primer Informe de Entrega de La ONIC Ala Jurisdicción Especial Para La Paz -JEP.” https://www.onic.org.co/comunicados-onic/2518-onic-entregoa-la-jep-informe-de-afectaciones-individuales-y-colectivas-sufridas-por-los-pueblosoriginarios-en-el-conflicto-armado.

Pineda, Roberto. 1997. "La Constitución de 1991 y La Perspectiva Del Multiculturalismo En La Constitución de 1991.” Alteridades 7 (14): 107-29. 
Presidencia de la República de Colombia. 2011a. "Decreto Ley de Víctimas No. 4633 de 2011. 'Por Medio Del Cual Se Dictan Medidas de Asistencia, Atención, Reparación Integral y de Restitución de Derechos Territoriales a Las Víctimas Pertenecientes a Los Pueblos y Comunidades Indígenas'.”

http://www.centrodememoriahistorica.gov.co/descargas/registroEspecialArchivos/D ecreto4633-2011-ley-de-victimas.pdf.

__ 2011b. "Decreto Ley 4635 de 2011. 'Por El Cual Se Dictan Medidas de Asistencia, Atención, Reparación Integral y de Restitución de Tierras a Las Víctimas Pertenecientes a Comunidades Negras, Afroc\%mbianas, Raiza/Es y Palenqueras'.”

—_ 2018. "DECRETO 1167 DE 2018. 'Por El Cual Se Modifica El Artículo 2.15.1.1.16 Del Decreto 1071 de 2015, Decreto Único Reglamentario Del Sector Administrativo Agropecuario, Pesquero y de Desarrollo Rural, Relacionado Con Las Zonas Microfocalizadas.'”

https:/www.funcionpublica.gov.co/eva/gestornormativo/norma.php?i=87361.

Radcliffe, Sarah A. 2017. "Geography and Indigeneity I: Indigeneity, Coloniality and Knowledge." Progress in Human Geography 41 (2): 220-29. https://doi.org/10.1177/0309132515612952.

Raiz Al Centro del pensamiento latinoamericano. 2015. "Apuntes Sobre Procesos de Despojo/Privilegio.” Revista Intervenciones En Estudios Culturales 2: 35-41.

Redacción Judicial. 2019. "Corte Constitucional Amplió La Vigencia de La Ley de Víctimas.” El Espectador, December 5, 2019.

https:/www.elespectador.com/noticias/judicial/corte-constitucional-amplio-lavigencia-de-la-ley-de-victimas-articulo-894429.

Ruiz, Daniel. 2017. "El Territorio Como Víctima. Ontología Política de Las Leyes de Víctimas Para Comunidades Indígenas y Negras En Colombia." Revista Colombiana de Antropología 53 (2): 85-11. 
UARIV Unidad de Atención y Reparación Integral Para las Víctimas. 2019. "Victimas Registradas a Diciembre 1 de 2019." December 1, 2019. https://cifras.unidadvictimas.gov.co/.

UNDP-United Nations Development Programme. 2019. "Wuasikamas, El Modelo Del Pueblo Inga En Aponte, Colombia. Estudios de Caso de La Iniciativa Ecuatorial." UNDP New York. https://www.equatorinitiative.org/wpcontent/uploads/2017/05/Wuasikamas-Colombia-Spanish.pdf.

Unidad para la atención y reparación integral a las víctimas. 2017. "Más de 1,2 Millones de Víctimas Étnicas Dejó El Conflicto Armado En Colombia." October 10, 2017. https://www.unidadvictimas.gov.co/es/asuntos-etnicos/mas-de-12millones-de-victimas-etnicas-dejo-el-conflicto-armado-en-colombia/39543. 